\title{
Diplomates Certified in 2007
}

The American Board of Genetic Counseling

Published online: 7 May 2009

(C) National Society of Genetic Counselors, Inc. 2009

Erratum to: J Genet Counsel (2008) 17(6):652-654

DOI 10.1007/s10897-008-9195-7

The American Board of Genetic Counseling (ABGC) regrets the omission of Jennifer Nuk from the list of Diplomates Certified in 2007. Congratulations to Jennifer and to all the Diplomates who achieved ABGC certification in 2007.

The online version of the original article can be found at: http://dx.doi. org/10.1007/s10897-008-9195-7

The American Board of Genetic Counseling 